\title{
Czerwone buty i „bosość” stóp, czyli „substytut braku” w Janie Tajemniku Bolesława Leśmiana
}

\author{
Red Shoes and "Barefootedness," i.e. "Substitute for Absence" in Jan Tajemnik [John \\ the Mystery Man] by Bolesław Leśmian
}

Abstract: The author of the article reflects on the issue of it not being cognitively possible to understand an alienated individual. She presents the character of the fable as an emblem of a suffering, dramatically self-aware being. Revealing the secret results in the stigmatisation of the individual with the tragedy of consciousness and suspends him in the unnamed perceptional interworld. The author analyses the philosophical contexts of the text and characterises Leśmian's ontology. The themes of fables and Biblical rules become a rich and meaningful background to the reflections provided.

Keywords: John the Mystery Man, Bolesław Leśmian, Polish Fables, barefootedness, red shoes

Streszczenie: Autorka artykułu rozważa kwestię niemożności poznawczej wyobcowanego indywiduum. Prezentuje bohatera klechdy jako emblemat cierpiącego, dramatycznie świadomego siebie istnienia. Odsłonięcie tajemnicy nieodwracalnie piętnuje jednostkę tragizmem świadomości i zawiesza w nienazwanym percepcyjnym międzyświecie. Autorka analizuje filozoficzne konteksty utworu i charakteryzuje Leśmianowską ontologię. Bogatym znaczeniowo tłem wysuwanych refleksji staje się tematyka ludowych bajań i biblijnych prawideł.

Słowa kluczowe: Jan Tajemnik, Bolesław Leśmian, Klechdy polskie, bosość, czerwone buty 
W szyciu nic nie ma, oprócz szycia, Więc szyjmy, póki starczy siły! W życiu nic nie ma, oprócz życia, Więc żyjmy aż po kres mogiły!

B. Leśmian, Szewczyk ${ }^{1}$

Rozważania podjęte w tym artykule dotyczą ontologicznego problemu braku i niemożności poznawczej w klechdzie Bolesława Leśmiana Jan Tajemnik. Do właściwego odczytania tekstu niezbędne jest zarówno uwzględnienie kontekstów całej prozy Leśmiana, jak i odwołanie do koncepcji i motywów, w które obfituje jego dorobek poetycki. W nawiązaniu do słów Piotra Matywieckiego można stwierdzić, że: „wejście do baśni Jan Tajemnik prowadzi przez znajomość poezji Leśmiana. A do poezji Leśmiana jest wejście przez Jana Tajemnika”3.

Perypetie związane z historią powstania i wydania klechd mają wpływ na ich fabuły ${ }^{4}$. Kreślone w nich uniwersum tworzy zamkniętą strukturę, w obrębie której przeprowadza się analizę mechanizmów rządzących życiem, społecznością i człowiekiem. Ów świat klechd stanowi odzwierciedlenie ontologicznego porządku wszechrzeczy - jego niby jednorodny, ale jednak niestabilny, a nieuporządkowany status jest, jak dowodzi Dariusz Szczukowski, „przestrzenią poszukiwania "kontaktu bezpośredniego z życiem "”

Klechdy polskie w pierwotnym zamyśle miały zostać skierowane do najmłodszych czytelników. Z bajek dla dzieci zrodziły się jednak filozoficznie niejednoznaczne baśnie ${ }^{6}$ dla dorosłych ${ }^{7}$. Zgodnie ze stwierdzeniem Wacława Lewandowskiego, „[ś] rodkiem poznawczych i kreacyjnych zabiegów jest (...) swoisty synkretyzm elementów baśniowych i folklorystycznych. Z nich budowane są

1 B. Leśmian, Szewczyk [w:] tegoż, Poezje wybrane, oprac. J. Trznadel, Wrocław 1983, s. 98.

2 Michał Paweł Markowski w swojej książce określa Leśmiana „poetą braku”, nieobecności i negacji. Twórczość Leśmiana naznaczona jest piętnem „niedowcieleń”. Por. tenże, Polska literatura nowoczesna. Leśmian, Schulz, Witkacy, Kraków 2007, s. 98, 147, 151.

3 P. Matywiecki, Czyściec (o baśni Bolestawa Leśmiana Jan Tajemnik), s. 109, http://www. kwartalnik.art.pl/wp-content/uploads/2015/06/kwartalnik17.pdf, dostęp: 20.11.2018.

${ }^{4}$ Zob. D. Pachocki, Filologia i historia. "Klechdy polskie" Bolestawa Leśmiana i inne urwane tropy, „Teksty Drugie” 2014, nr 2 [tu: problemy z wydaniem, usuwanie fragmentów fabuły, zagubienie rękopisów, brak dowodów na autentyczność odpisów].

5 D. Szczukowski, „Bajka, która baje”. O kilku motywach w „Klechdach polskich” Bolestawa Leśmiana, „Jednak Książki” 2017, nr 7, s. 100.

${ }^{6}$ Bogate studium na temat baśni i baśniowości w literaturze młodopolskiej (w tym także rozdział poświęcony kategorii baśni w twórczości Leśmiana) oraz ich związków z mitem i folklorem przeprowadzone zostało przez Czabanowską-Wróbel. Badaczka definiuje baśń ludową jako „ludow[ą] ustn[a] bajk[ę] magiczn[a] , ale także zapisany utwór literacki o większych lub mniejszych związkach z folklorem”. Taż, Baśn w literaturze Mtodej Polski, Kraków 1996, s. 10.

7 Obecne są w nich liczne nawiązania do filozoficznych koncepcji, a mianowicie idea rzeczy samych w sobie, agnostycyzm, witalizm, egzystencjalizm, ontologia reprezentowanych przez Immanuela Kanta, Henriego Bergsona, Sørena Kierkegaarda, Jeana Paula Sartre’a, Arthura Schopenhauera, Martina Heideggera. 
owe nieprawdopodobne światy, powoływane do istnienia i poddawane uważnemu oglądowi"'.

Baśń Leśmianowska ma charakter epistemologiczno-aksjologiczny, ,jest światopoglądem, metodą rozszerzania granic ludzkiej rzeczywistości, formą metafizycznego poznania" "Zderzenie dyskursów: filozoficznego i baśniowego zachęca do podjęcia próby znalezienia odpowiedzi na fundamentalne pytania dotyczące sfery bytu i epistemologicznej inicjacji ${ }^{10}$. Baśn - jak twierdzi Anna Czabanowska-Wróbel - „jest nie tylko nazwą gatunkową (...), ale także znaną nam już Leśmianowską kategorią ontologiczną sygnalizującą istnienie innej, pełniejszej rzeczywistości” ${ }^{11}$. Antynomie i bogate znaczeniowo motywy kreują baśniowy krajobraz, któremu zostaje nadana własna podmiotowość. „Proza poetycka Leśmiana - pisze dalej badaczka - (...) jest próbą wyrażenia za pomocą uniwersalnego języka symboli zaczerpniętego "ze snów, baśni i mitów « filozoficznej interpretacji stanu, w jakim znalazł się człowiek pozbawiony metafizycznej nadziei i zwrócony jedynie w stronę śmierci” ${ }^{12}$. Zastosowanie elementów fantastycznych wobec zjawisk rzeczywistych i nadanie im filozoficznych treści sprawia, że baśń staje się studium natury ludzkiej i przeradza się w wykład o filozofii istnienia.

Tłem rozważań nad klechdami Leśmiana jest rzeczywistość wiejskiej przestrzeni, a symbolika poszczególnych przedstawień głęboko osadzona zostaje w tradycjach, obrzędach i wierzeniach folklorystycznych. Znaczenia związane z topiką rustykalną odwołują się w istocie do sensów głębszych, niż wskazuje na to sama treść zagadnień ontologicznych. Akcentuje to Michał Głowiński, konstatując, że „Leśmian nie jest nigdy stylizatorem. Z ludowości czerpie jedynie to, co jest mu potrzebne do konstrukcji jedynej i niepowtarzalnej wizji świata. Ludowość nie jest bowiem wzorem, ale pożywką wyobraźni”'13. Lidia Ligęza stwierdza z kolei: „Najczęściej ludowa fabuła jest pretekstem do ukazania i uogólnienia jakiejś prawdy filozoficznej lub symbolu losu ludzkiego"14.

Ludowość staje się sferą uniwersalną, wręcz mityczną, stanowi bowiem formę najbliższego kontaktu z przestrzenią pierwotności. Baśniowy optymizm poznawczy, obecny w ludowych bajaniach, ich niepowtarzalna magiczność,

${ }^{8}$ W. Lewandowski, Wstęp [w:] B. Leśmian, Klechdy polskie, wstęp, oprac. W. Lewandowski, Kraków 1999, s. 35.

9 A. Czabanowska-Wróbel, dz. cyt., s. 234.

${ }^{10}$ Czabanowska-Wróbel pisze o trzech poziomach poznania. Zwracając uwagę na wielopłaszczyznowość literackiego sensu, ujmuje istotę Leśmianowskiej baśni. Połączenie naiwnej magiczności z empiryzmem i racjonalnością owocuje w intuicyjne i irracjonalne, a więc poetyckie widzenie rzeczywistości, w którym kryje się filozoficzna prawda klechd. Zob. tamże, s. 232.

11 Tamże, s. 207.

12 Tamże, s. 215.

${ }^{13}$ Cyt. za: tamże, s. 226.

${ }^{14}$ L. Ligęza, „Klechdy polskie” Bolestawa Leśmiana na tle folklorystycznym, „Pamiętnik Literacki” 1968, nr 1, s. 113. 
zestawione z sakralnym wymiarem mitycznego przekazu i jego archetypicznym ucieleśnieniem sprawiają, że baśń splata się z mitem, a symboliczna opowieść staje się nośnikiem głębokiego znaczenia egzystencjalnego ${ }^{15}$. Baśń, poprzez metaforyczne zobrazowanie psychologicznej oraz filozoficznej głębi, prowadzi do obnażenia podświadomości i umożliwia modelową analizę ludzkich postaw ${ }^{16}$.

Światem natury, z którym nieodłącznie wiąże się istnienie postaci, rządzi dynamizm życia. Bohaterowie to silnie wyodrębnione indywidualności naznaczone niedookreślonym poczuciem tęsknoty i pragnieniami. Brzydota, kalectwo, swoista „bosość” i inne defekty charakteryzują życie w jego pełni i kładą akcent na siły witalne, które przepełniają egzystencję tych postaci. Człowiek jest ubogi, ułomny i w tych niedoskonałościach tkwi siła życia. Jest on wzięty z natury i jako taki powinien trwać - szczęśliwy we własnej niepoznawalności, ale pełen istnienia samego w sobie. Bogactwo osobowości, symboliki oraz pierwotnych związków z życiem sprawiają, że bohaterowie z ludu obdarzeni są naturalnym witalizmem i związaną z nim mocą kreacji.

Warte uwagi są również kwestie społecznych uwarunkowań kulturowych, a mianowicie rozgraniczenia między warstwą chłopską a stanem szlacheckim. Objawia się to nie tylko w samej charakterystyce Tajemnika, ale także w sposobie kreacji bytów nadprzyrodzonych. Piętnująca je szlacheckość jest zgubna w każdej możliwej postaci, gdyż wszystko, co nią skażone, osiąga wymiar tragiczny.

Czerwone buty symbolizują stan szlachecki. Będąc własnością Upiora, przeznaczone są tylko do bytowania podziemnego. Przedmioty te wydają się diabelskie, a więc piękne, wyzywające i przyzywające, ale przede wszystkim zgubne, ponieważ stanowią wytwór cywilizacji i akcentują społeczną hierarchię. Owa sycąca czerwień, jarzący się szkarłat, skrząca się płomienistość, wiekuista purpura hipnotyzują i obezwładniają tego, który zapadnie się w nie spojrzeniem.

15 Czabanowska-Wróbel przedstawia krótko genezę mitu i baśni (zob. taż, dz. cyt.). Zestawiając teorie naukowców, dowodzi, iż nie można jednoznacznie orzec o pierwotności czy dawności tych gatunków (mityzacja czy remityzacja baśni?) wskutek ich nieustannej korespondencji. Problem ten rozwija już Bruno Bettelheim w swej pracy Cudowne i pożyteczne. Znaczenie i doniostość baśni, zwracając uwagę między innymi na wartość treści ukrytych w mitach i baśniach, które wyrażają stany ludzkiej podświadomości (zob. tenże, Cudowne i pożyteczne. Znaczenie i doniostość baśni, tłum. D. Danek, „Teksty. Teoria literatury, krytyka, interpretacja” 1980, nr 1). Powołując się na koncepcje Bettelheima i Mircei Eliadego, można wyodrębnić kilka istotnych tez. Mit jako niezbywalny element tradycji danej społeczności, odwołujący się do praźródeł, naznaczony jest pesymizmem poznawczym i nienaruszalną pierwotnością przekazu. Wpisany weń sakralny wymiar i podniosły ton tworzą scenerię dla zdarzeń wrzuconych w cykl mitycznego czasu. Mit jest sferą ponadczasowej inicjacji, nadając bowiem egzystencjalne znaczenie metaforycznym treściom, wnika w prawdę o człowieku i transcendencji. Baśniom z kolei patronują sielankowa cudowność, ludyczny charakter i satysfakcjonujący optymizm. Baśniowe motywy są odbiciem treści ludzkiej psychiki (podobnie jak marzenia senne) i natury, co sprawia, że istotą baśni staje się konfrontacja jej treści z egzystencjalnymi problemami człowieka.

16 Por. B. Bettelheim, dz. cyt., s. 175. 
Buty „zdradzają nieprzepartą chęć skrzesania ognia podkówkami”"17 - jako pragnienie poznania kierują ludzką żądzą dojścia do niezgłębionej w swej istocie prawdy o świecie i sobie samym.

Jarosław Marek Rymkiewicz w swojej encyklopedii Leśmiana analizował między innymi problem „obucia” i „bosości” obecny w klechdach i w poezji ${ }^{18}$. Wielość sytuacji narracyjnych i symbolicznych odczytań sprawiają, że nie można jednoznacznie orzec, który z ontologicznych statusów jest właściwy ludzkiej naturze: „Lepiej więc chodzić na bosaka, czy chodzić w butach? Lepiej mieć buty, czy ich nie mieć? (...) Nie wiadomo"19. Zgodnie z Leśmianowską koncepcją uwidaczniającą się podczas analizy większej grupy jego utworów (Majka, Podlasiak, W zakątku cmentarza, Otchtań, Szewczyk, Łąka), dusza umiejscowiona jest w nogach, a bose bądź obute stopy są sygnałem metafizycznej istotowości. Rymkiewicz stwierdza jednak, że: „bosość - nie jest, wedle Leśmiana, czymś, co koniecznie związane jest z człowieczeństwem, bose mogą bowiem być $\mathrm{i}$ bywają również inne istnienia" ${ }^{20}$. Badacz akcentuje przez to fakt, iż buty, same w sobie, są odzwierciedleniem duchowej esencjonalności bytu. W Janie Tajemniku są wręcz ontologicznie osobnym istnieniem i nie podlegają woli Tajemnika, gdyż charakteryzują się własną - szlachecką podmiotowością, co sprawia, że są zupełnie obce chłopskiej naturze bohatera. Buty, jako symbol niezależnej od ludzkiej woli transcendentnej tajemnicy, są pokusą, za którą płaci się własną wiecznoś$\mathrm{cią}^{21}$, a człowiek jest bezradny wobec istnienia, które rozgrywa się samo w sobie.

Niepoślednim nadprzyrodzonym bytem zaczerpniętym z folklorystycznych wyobrażeń jest w klechdzie Upiór, najprawdopodobniej pan zamku, który upomina się o swoją własność i pośredniczy w procesie odtajemniania. Ogranicza się do stwierdzenia: „Oddaj buty, oddaj buty!”22, co dowodzi, iż Upiór sam jest $\mathrm{w}$ tym momencie bosy - okradziony z istotowości. Twór barczysty, a jednocześnie nieludzko bezcielesny, wydziela zapach mogilny i wsącza w nozdrza Tajemnika trupi jad. Obfite wąsy i brwi zjawy nie tylko są symbolem szlacheckiej genealogii, lecz także stanowią o jej demonicznej proweniencji ${ }^{23}$. Tuż przed odzyskaniem butów, „[u]piór wąsa pokręcił, brwi przymarszczył, a potem dłonie obydwie wyciągną przed siebie, poruszając skwapliwie palcami, jakby chciał coś pochwycić" ${ }^{24}$. Biorąc udział w locie - w procesie złożonym i uświadamiającym - widmo bezpowrotnie odziera Tajemnika z samowolnie przywłaszczonego obuwia i nabytej wraz z nim obcej tożsamości.

17 B. Leśmian, Jan Tajemnik [w:] tegoż, Klechdy polskie, dz. cyt., s. 90.

18 J.M. Rymkiewicz, Leśmian. Encyklopedia, Warszawa 2001, s. 38-41.

19 Tamże, s. 41.

20 Tamże, s. 40.

${ }^{21}$ W tejże wieczności pogrążony jest Upiór - prawowity, przyrodzony właściciel butów, ich istotowy posiadacz, a więc nieoderwalna część składającej się na nie „istnieniowej wartości”.

${ }^{22}$ B. Leśmian, Jan Tajemnik, dz. cyt., s. 90.

${ }^{23}$ Zob. K. Moszyński, Kultura ludowa Stowian, t. 2, Warszawa 1967, s. 606.

${ }^{24}$ B. Leśmian, Jan Tajemnik, dz. cyt., s. 88. 
Diabeł pojawiający się w świetle księżyca na młyńskim kole ${ }^{25}$, co charakterystyczne dla ludowych wyobrażeń, jest również przedstawicielem stanu szlacheckiego ${ }^{26}$. Świadomy swej rangi społecznej i wyższości nad Tajemnikiem, jawnie podkreśla: „Zbyt podłego jesteś pochodzenia i zbyt, pomimo przydomku, nieznanego nazwiska, abym miał cię usynowić i ojcowaniem dookoła ciebie się zatrudniać" ${ }^{27}$. Piórkowski jest częścią rzeczywistości i swoim zniknięciem nagle podważa jej sens. Przejmuje pozorną kontrolę nad światem, który po jego zniknięciu jest moralnie zdestabilizowany. Mimo iż pojawia się w ludzkiej postaci, jednak ma pewne cechy zwierzęce (na przykład kosmatą dłoń) ${ }^{28}$. Wyposażony został w cały zestaw atrybutów i zachowań charakterystycznych dla ludowych wyobrażeń Złego. Respekt wzbudzają w nim zapobiegawcze zaklęcia i zabobonne odczyniania, uznawane przez prosty lud za środki obrony przed piekielnymi mocami ${ }^{29}$. Diabeł ma jednak władze nad człowiekiem - pęta spojrzeniem, ponieważ patrząc, przyciąga i kusi. Zagląda w duszę ludzką do tego stopnia, że zapada się w nią. Podziemny świat i jego jaśniejące skarby, mimo iż naznaczone są szatańskim piętnem, fascynują i przyciągają ${ }^{30}$. W tę przestrzeń wkracza Tajemnik i oddaje się pod szatańską kuratelę. Po utracie butów i na skutek moralnego obnażenia, bohater „osmala się” wstydliwym rumieńcem. Diabelska sztuczka zaślepia umysł, co sprawia, że pokusa przejmuje władzę nad wyczuloną intuicją.

Użycie motywów nadrealistycznych uwydatnia ograniczenia możliwości percepcyjnych jednostki wobec rzeczywistości i natury. Dlatego też ontologiczna przestrzeń w klechdzie rozpięta jest między równoległymi bytami - każdy $\mathrm{z}$ baśniowych tworów charakteryzuje się pełnoprawnym istnieniem i jako abstrakcyjna kreacja nabiera cech człowieczych. „Las - jak pisze Czabanowska-Wróbel - w który można się zagłębić, jest często symbolem psychiki i jej penetracji”" ${ }^{31}$. Las wydaje się magiczny, a noc w nim pełna mroku i dzikości zagniewana, nieokiełznana, a jednocześnie przesycona zadumą nad ułomnością człowieka i człowieczeństwa. Jednostka ludzka staje się integralną częścią

25 Zob. A.M. di Nola, Diabet, tłum. I. Kania, Kraków 2000, s. 318-319. Symbolika młyna w wyobrażeniach ludowych oscyluje wokół przedstawień ukazujących tę przestrzeń jako siedlisko upiorów, diabłów i rustykalnych demonów (Młyn Diabelski - zob. tamże, s. 325). Ta rzeczywistość jest złowroga dla człowieka, a towarzysząca jej sceneria (światło księżyca, noc, w czasie której pojawia się szatan) jawi się jako złowieszcza. Jednak te okoliczności nie przerażają Tajemnika, który uparcie penetruje mityczne krainy.

${ }^{26}$ Ligęza stwierdza, że: „Leśmianowski czart jest zatem postacią w typie ludowym, wywodzącą się ze średniowiecza”. Tenże, dz. cyt., s. 120.

27 B. Leśmian, Jan Tajemnik, dz. cyt., s. 76.

${ }^{28}$ Spośród opracowań dotyczących dziejów motywu w kulturze i wyobrażeń postaci diabła w mentalności w ciągu epok wyróżnić należy także: M. Rożek, Diabet w kulturze polskiej. Szkice zdziejów motywu i postaci, Kraków 1993. Zob. zwłaszcza rozdz. Ludowa wizja ztego, s. 188-218.

29 Por. tamże, s. 182-184.

30 Zob. A.M. di Nola, dz. cyt., s. 325-326.

31 A. Czabanowska-Wróbel, dz. cyt., s. 230. 
tej natury, wobec czego ich byty wzajemnie się przenikają i „[d]latego też natura w tym samym stopniu patrzy na człowieka, co i człowiek na naturę"32.

Zmienność bytów, a także złożoność i spójność ich postaciowości (podmiotowości wcielonej w przedmiotowość) realizują się w wolności, w której dokonuje się ciągłe stwarzanie rzeczywistości z całym jej dynamizmem istnienia $^{33}$. Wszystko, co istnieje, zyskuje miano osobnej indywidualności utkwionej w egzystencji. A „wszędzie tam, gdzie jest życie, gdzie jest wola życia, choćby w szczątkowej formie, tam jest wolność"34. Pojmowana bywa jako brak ograniczeń dla twórczej mocy istnienia. Wolne okazuje się to, co żyje w naturze i nie pyta o przyczynę, co żyje życiem samym w sobie, w zgodzie z istotą życia. Jednakowoż warunkiem trwania w pełni wolności wydaje się przebywanie w przestrzeni pierwotnej bezświadomości. Wszystko bowiem, co dostąpiło poznania formalnych granic, uwięzione zostało w wolności tragicznej. Paradoksalnie, ta skrępowana wolność jest świadomością istnienia uprzedmiotowionego kształtu ${ }^{35}$, a próba wyjścia poza głębię własnej natury okazuje się pragnieniem nierealnym i zabójczym.

Dlatego też poczucie braku oraz ontologiczna niemożność zakorzenienia stanowią oś kompozycyjną, wokół której osnuty został utwór Leśmiana. Wszystko, co bytuje, oprócz silnie nakreślonej indywidualności odznacza się znamionami świadomości i wskutek zaburzenia pierwotnej harmonii z życiem odczuwa poznawczy niedosyt. Bronisław Przyłuski konstatuje: „Rzeczywistość jest jakby innymi oczami oglądana, logika inna, tęsknota pozazmysłowa, a dziwność prosta i normalna. Postacie ludzkie żyją w tym wielorakim świecie niezwykle, nie przestając żyć zwyczajnie. A zwidy tęsknią do codziennego życia” ${ }^{36}$. Każdy przebłysk jaźni nasycony jest iluzyjnością i tragizmem egzystencji ${ }^{37}$. Nie da się dostąpić poznania, jeżeli nie można wyjść poza własną formę. Przestrzenią klechd rządzi zatem przekonanie o ontologicznej niedookreśloności. Byty tracą

32 C. Rowiński, Cztowiek i świat w poezji Leśmiana. Studium filozoficznych koncepcji poety, Warszawa 1982, s. 42.

33 „Istnienie w poezji Leśmiana” - pisze Nawrocki - „przypomina ocean wrzącej lawy. (...) to, co jest wedle Leśmiana istnieniem, jest bezkresne i bezdenne. (...) Istnienie wrze, a wrząc eksploduje w nieprzewidywalnych formach, które pojawiają się niespodziewanie i nagle, a giną tak, jak się pojawiły. (...) Nie ma mowy o przyczynowości, nie ma mowy o konieczności. To, co jest - jest. I wrze". M. Nawrocki, Wariacje istnieniowe. O ontologii poetyckiej Bolestawa Leśmiana, Tarnów 2009, s. 7.

${ }^{34}$ C. Rowiński, dz. cyt., s. 193.

35 Pisze dalej Nawrocki: „świadomość dana jest formom istnieniowym, które z wrzącego oceanu wyłaniają się i które we wrzącym oceanie giną. Właściwie świadomość (...) jest samą eksplozją. I jest samym ginięciem. Dlatego (...) wszystko, co istnieje - cierpi”. Tenże, dz. cyt., s. 8.

${ }^{36}$ Cyt. za: A. Czabanowska-Wróbel, dz. cyt., s. 228.

37 Nawrocki dodaje: „Jest moment zaistnienia, jest błysk świadomości wyłaniającej się z wrzącego oceanu, jest błysk poznania i jest błysk świadomości zapadającej w ocean, który wrze i nie stygnie”. Por. tenże, Wariacje istnieniowe..., dz. cyt., s. 8. 
podmiotowość i jakąkolwiek możliwość decydowania o własnym losie. Zgłębiają swoją istotę, lecz nie mogą się ani od niej uwolnić, ani być z nią w sprzeczności.

„Świat i zaświat Leśmiana - jak twierdzi Głowiński - jest piekłem ustawicznego stwarzania się i znikania istot w męce bytu i w męce niebytu" ${ }^{38}$. Zjawiska łączą się i dwoją, rozdzielają i przenikają w niezgłębionej ciszy własnej egzystencji ${ }^{39}$. Ziemia wzdycha, ciemność piętrzy się wśród drzew i zmaga z własnym nadmiarem. Wszystko przesycone jest głębią niewyczerpanej istoty i ograniczone zwartą strukturą zewnętrzności. Jak pisze Matywiecki:

„Dramat Formy” w szczególny sposób przejawia się w niezwykłym statusie magicznych jestestw i przedmiotów. (...) [U] Leśmiana one są magiczno-mowne, nieskończenie głęboko zanurzające się w siebie. Dlatego jego baśń jest ontologiczna, to baśn bytu rzeczy i bytu mowy. Istota rzeczy i słów jest wewnętrznie niewyczerpywalna, jednak zewnętrznie ograniczona Formą. Każdy magiczny element ma swoją czynnościową istotę, jest rzeczownikiem swego czasownika i czasownikiem swego rzeczownika, jest Formą (zdaniem) samego siebie! ${ }^{40}$

Ilekroć pada polecenie: „[s] krzep się w sobie”41, tyle razy byt zgłębia swoją i tylko swoją esencję. Wszelkie istnienie napiętnowane jest świadomością, co sprawia, że boleśnie kontempluje swą kondycję: „Coś w niej tylko westchnęło, zapodziało się w sobie, ułożyło się wygodniej i znieruchomiawszy, zamilkło. Westchnęło niemal po człowieczemu, a zamilkło zgoła nie po ludzku”’². Zniewolenie podsycane jest pragnieniem wyjścia poza życie, które patronuje zarówno abstrakcjom, bytom roślinnym, zwierzęcym, jak i ludzkim.

Historia Tajemnika ukazuje próbę konfrontacji bohatera z samym sobą i ze światem, w którym jest umiejscowiony. To opowieść o procesie obnażania postaci i docierania do sensu. Przedmiotem dociekań staje się istota człowieczeństwa, jego swojość, wnętrze i pozycja wobec potęgi egzystencji.

Człowiek w twórczości Leśmiana jest nieodłączną częścią natury. Charakteryzuje się rozwiniętą jaźnią, lecz stanowi substytut niedookreśloności. Jak pisze Jan Zięba:

Człowiek nie jest w żadnym momencie swego istnienia czymś gotowym, nie można znaleźć w nim jakiegokolwiek trwałego elementu, cokolwiek by nim miało być duch, czy materia. Byt, substancja - to złe określenia na człowieka, który jest

${ }_{38}$ M. Głowiński, Zaświat przedstawiony [w:] tegoż, Zaświat przedstawiony. Szkice o poezji Bolestawa Leśmiana, Kraków 1998, s. 299.

39 Por. M. Stala, Jam jest miejsce spotkania. Duch, dusza i ciato w poetyckiej antropologii Bolestawa Leśmiana [w:] tegoż, Trzy nieskończoności. O poezji Adama Mickiewicza, Bolestawa Leśmiana i Czestawa Mitosza, Kraków 2001, s. 87-88.

${ }^{40}$ P. Matywiecki, dz. cyt., s. 111.

${ }^{41}$ B. Leśmian, Jan Tajemnik, dz. cyt., s. 96.

42 Tamże, s. 80. 
pierwotnie samym stawaniem się, procesem kształtowania, czy może, w nowszym języku, egzystencją ${ }^{43}$.

Jako pełnoprawne indywiduum wpisuje się w przestrzeń pełni życia, choć paradoksalnie sam w owym istnieniu się gubi. Zostaje owładnięty żądzą posiadania, instynktownymi pragnieniami i to sprawia, iż zatraca się w wirze nieposkromionych penetracji.

Cezary Rowiński dowodzi, iż: „[c]złowiek Leśmianowski postawiony jest wobec nicości, wobec śmierci i jest samotny" ${ }^{44}$. Samotność w twórczości Leśmiana stanowi wartość poznawczą, ponieważ umożliwia wyrwanie się z okowów społecznych. Człowieka pierwotnego ${ }^{45}$ postrzega się tu jako indywidualistę obdarzonego dynamizmem życia ${ }^{46}$ i możliwością doświadczania jedności rzeczywistości. Nie został skażony dualizmem rzeczy (podziałem na podmiot i przedmiot, na wnętrze i formę) i może dojść do jedni, metafizycznego poznania. Chłopskie jestestwo, mimo iż realizujące się w społecznych konwenansach i ograniczone cywilizacyjnymi nacechowaniami, odznacza się naturalną skłonnością do bliskości z przyrodą i kontemplacji jej przestrzeni ${ }^{47}$, co sprawia, że jest najbliżej pierwotnego ideału. Leśmian kreuje człowieka z ludu jako indywiduum pierwotnie wolne od wszelkich społecznych uwarunkowań i dzięki temu zachowujące w dużej mierze swoją nieskażoną duchowość. Rowiński konstatuje, że „Leśmian chyba jako jeden z pierwszych tworzy koncepcję indywidualizmu, której obcy jest wszelki pierwiastek arystokratyczny" ${ }^{48}$.

Szlachectwo to stan uprzywilejowany, podlegający ustalonej hierarchii, przez co staje się obliczem zgubnej cywilizacji. Diabeł mianuje się „Panem Piórkowskim”, upiór - „Panem zamku”, a buty okazują się symbolem wyższej rangi społecznej. Każdy z wymienionych elementów ma negatywny wydźwięk, ponieważ przyczynia się do zguby bohatera. „Bosość” stóp jest ukazywana jako konsekwencja przynależności do chłopskiego stanu. To oznaka pierwotności wpisanej w istotę plebejskiej natury. Tajemnik stara się na siłę „wejść w cudze buty”“99 podejmując tę próbę, kradnie obcy sobie status społeczny i przez to wyzbywa się własnej, a zatem chłopskiej natury. Wcielając się w zupełnie obcą mu rolę,

43 J. Zięba, Bolestawa Leśmiana światopogląd nowoczesny. O eseistyce poety, Kraków 2000, s. 31 .

${ }^{44}$ C. Rowiński, dz. cyt., s. 52.

${ }^{45}$ Por. J. Zięba, dz. cyt., s. 51.

46 Zawarte jest w tym stwierdzeniu odwołanie do filozofii Bergsona i pojęcia élan vital.

47 Zięba pisze, iż „poznanie nie polega na konfrontacji psychicznego ludzkiego wnętrza z zewnętrzną przyrodą, ale jest czymś w rodzaju ekspansji tego człowieka na rzeczywistość, ruchem ciągłego wzmagania swojego istnienia, rodzajem biologicznej aktywności”. Tenże, dz. cyt., s. 51.

${ }^{48}$ C. Rowiński, dz. cyt., s. 38.

49 „Wchodzić w cudze buty” - znaczenie tej kolokacji określa kondycję człowieka, który wczuwa się w sytuację kogoś innego. Tajemnik, wyzuwając się z „bosości”, przyjmuje nową cudzą rolę, cudze istnienie i cudze jestestwo. 
wkracza w nową tożsamość i zaburza ustalony porządek. Proces ten unicestwia indywidualność, która stanowi o jestestwie bohatera. Można również domniemywać, że to cywilizacja gubi Tajemnika, zawłaszczonego przez dyktaturę skonwencjonalizowanych i usankcjonowanych społecznie norm.

Działaniami postaci kieruje chęć zaspokojenia pragnień. Ich ewokacja dokonuje się w sferze marzeń sennych, jednak nawet tam bohater nie ma nad nimi władzy: „Umiał Jan-Tajemnik takie buty czasami wyśnić po nocy, że nie wiedział nawet, jak je wzuć na nogi, snem dostatnim zaszczycone" ${ }^{50}$. Mrzonki i widziadła senne, urzeczywistniając się, zakłócają bieg wydarzeń. Wabiąc, odzierają bohatera z prawdziwości i wpędzają w złowrogą przestrzeń ułudy. Tragizm losów zostaje uwypuklony poprzez groteskowość i komizm przejawiający się w irracjonalnych czynach, nieświadomego konsekwencji własnego postępowania, Tajemnika. Mężczyzna, zaślepiony czerwienią, nie boi się upiora ani śmierci, ale rozłąki z obiektem najskrytszych marzen ${ }^{51}$. Ułomny, słaby i bezradny wobec nadmiaru, a mimo to groteskowo „[p]atrzy i wnioskuje” ${ }^{52}$. Jego działaniami kieruje intelekt, który odbiera mu zdolność intuicyjnej percepcji. Zapewniony o autentycznej czerwieni butów, odpowiada: „Tedy pragnę ich całym rozumem swoim!" ${ }^{3}$. Mylą go zmysły i myli go rozum, jednak to na ich podstawie bohater dokonuje oceny rzeczywistości i jest przekonany o słuszności swojego stanowiska, co tym bardziej akcentuje groteskowość tego przedstawienia. Tajemnik z chwilą zawłaszczenia butów traci swoją „,bosość”. Kryzys tożsamości dojrzewa w nim i dostrzega to nawet sam bohater:

Śpieszno mi do tego, aby się ze sobą samym, jako z osobą bogatą, zżyć i porozumieć stosownie, bo już ja nie ten, co dawniej, więc mi nie przystoi po dawnemu siebie traktować. A nie wiem jeszcze, jak mam siebie traktować i jak się dookoła własnej osoby krzątać, bo wszystkiego trza się nauczyć. Czy za pan brat być ze sobą, czy nie za pan brat? ${ }^{34}$

Okazuje się jednak, że „zbratanie się” z nabytym i jednocześnie zabójczym dla kondycji bohatera nowym wizerunkiem jest niemożliwe, jego forma bowiem śmiertelnie obarcza nieprzystosowaną do niej chłopską duszę. Bunt wobec społecznych norm i niepodważalnych systemów aksjologicznych prowadzi

${ }^{50}$ B. Leśmian, Jan Tajemnik, dz. cyt., s. 71.

${ }^{51}$ Tajemnik nazywany jest „Poszukiwaczem strachu” - nie zna strachu w kontakcie z rzeczywistością nadprzyrodzoną, boi się jedynie utraty butów czerwonych (zob. L. Ligęza, dz. cyt., s. 116).

52 B. Leśmian, Jan Tajemnik, dz. cyt., s. 79.

53 Tamże, s. 75. Przykazanie miłości „Będziesz miłował Pana Boga swego całym swoim sercem, całą swoją duszą i całym swoim umysłem” (Mt 22, 37; Łk 10, 27: „całą swoją mocą”) zostaje przeniesione z sfery biblijnej w rzeczywistość szatańską. Zamiast Jezusa - diabeł Piórkowski, zamiast miłości - pragnienie, zamiast człowieka - buty.

${ }^{54}$ B. Leśmian, Jan Tajemnik, dz. cyt., s. 83-84. 
Tajemnika do klęski. Zanegowane zostaje to, co stanowi o nim samym. Bohater, zrzekając się chłopskości i związanej z nią boskiej protekcji, zapiera się siebie jako pełnoprawnego i niezależnego bytu, a także zrzeka się życia, gdyż działając w sprzeczności z własną naturą, unicestwia ją. Sprowadza się to do prostej zależności: pragnąc butów, dąży do śmierci.

Stan pozornego posiadania jest tylko iluzją spełnienia. W sensie filozoficznym życie samo w sobie jest naznaczone „bosością” stóp czy inaczej pojmowaną ograniczonością. Nie można uciec od przyrodzenia, czyli od istoty rzeczy, która jest w nią wpisana i o niej stanowi. Tajemnik przechodzi proces odtajemniania i uświadomienia. Buty czerwone są pretekstem do obnażenia prawdy o nim samym. Wszystko, co jest, konsekwentnie dąży do wniknięcia w głębię tylko po to, by odkryć jej otchłań. Wacław Lewandowski stwierdza, że bohaterem Leśmiana kierują „niedookreślone tęsknice”, a „podsycanie rzeczywistości" staje się siłą motywującą do określonych działań ${ }^{55}$. Pogoń za pragnieniem i próba ślepego zaspokojenia głodu poznawczego pociagają za sobą poważne następstwa. Tajemnik traci nie tylko pełnoprawną podmiotowość, ale także podwaliny moralne, na których opierały się jego dotychczasowe przekonania. Symboliczne wyrzeczenie się znaku krzyża przy pierwszym spotkaniu z Piórkowskim zamyka Tajemnikowi drogę powrotną do samego siebie. Zostaje zawieszony w pustce oczekiwania i jednoczesnego zmagania - rozgrywa się wielki dramat poznawczy naznaczający bohatera tragizmem świadomości.

Jak już wcześniej dowodziłam, natura współistnieje z człowiekiem, podzielając jego los i egzystencjalną kondycję. Wielość porządków rzeczy, wielość przestrzeni i wymiarów kreślą przestwór, w którym gubi się zarówno Tajemnik, jak i „istnienie samo w sobie” ${ }^{56}$. Lewandowski pisze, że „[w] szechświat jest gigantycznym zbiorem nieskończenie wielu istnień, nieustannie przemieniających się bytów, które w wielości i zmienności swojej składają się na nieograniczoną liczbę światów, budujących kosmiczną wszechjednię, z której tylko człowiek, jako wyposażony w świadomość, został wyobcowany" ${ }^{57}$. Porwany przez Upiora Tajemnik, odwrócony „do góry nogami”, wkracza w sfery, które wysysają z niego życie ${ }^{58}$. Niesiony w locie bohater zatraca poczucie czasu, podobnie jak zatraca poczucie egzystencji. Jest z nich brutalnie wydarty i otoczony wrogimi naturze ludzkiej, wszechobecnymi otchłaniami. Dostrzega jednakże nasilający się w nich niepokój, niedosyt i jakieś „zatroskanie”. Każda kraina

55 W. Lewandowski, dz. cyt., s. 50.

${ }^{56}$ Leśmian wychodzi od terminologii filozofii Immanuela Kanta (rzecz sama w sobie), jednak przekształca koncepcję według swojego zamysłu. Różnica polega bowiem na rozdzieleniu fenomenu i noumenu. Jak stwierdza Rowiński, Leśmian „dąży do przedarcia się poza pozory zjawisk w ich głąb, do rzeczy samej w sobie”. C. Rowiński, dz. cyt., s. 183.

57 W. Lewandowski, dz. cyt., s. 57.

58 Anna Czabanowska-Wróbel motyw lotu wiąże nierozerwalnie z nadprzyrodzonymi zjawiskami, czyli występowaniem postaci Upiora. Por. taż, dz. cyt., s. 227. 
naznaczona jest swoistym brakiem, zniewoleniem i „cierpieniem świadomego siebie istnienia" 59 .

Owa obcość, nieswojość sprawiają, że Tajemnik odzierany jest z wszystkiego, co stanowiło jego istotę. „Lot nocą objęty” przejmuje zgrozą nadmiaru. Bohater utwierdzony blisko ziemi jest jednocześnie blisko życia - wznosząc się w zaświaty, kolejno wyzbywa się chłopskości (obsesyjne pragnienie butów), niewinności (w chwili kradzieży butów i zaparcia się Boga), iluzji posiadania (moment, kiedy buty same zaczynają tańczyć), porządku rzeczy (niepoddanie się prawu przyciągania), świata, czasu, a w końcu godności (wstyd z powodu nagości), podmiotowości i wreszcie samego istnienia. Głowiński konstatuje: „Leśmianowski przybysz w zaświaty nie zaznaje wiecznego spokoju, przeciwnie - jest wiecznym tułaczem" ${ }^{\prime 0}$. Jego włóczęga to nieustanna pogoń za nieuchwytnym:

to jakaś Kainowa wędrówka bez odpoczynku i wytchnienia, z tą różnicą, że nie od miasta do miasta, a od świata do świata wiodąca, w coraz to nowe obszary rzeczywistości. Siłą napędową tego wędrowania jest głód poznania, zjednoczony z pragnieniem Miłości, silniejszy niż lęk i pokusa stabilizacji ${ }^{61}$.

Tajemnik, jak Odys, przemierza krainy i niczym Hiob - ten, który jest doświadczony przez Boga - wznosi rękę ku niebu, by odzyskać utracone jestestwo.

Lot jest czasem gruntownego zgłębienia prawdy o sobie ${ }^{62}$. To podczas niego rozgrywa się walka o duszę bohatera i jego istotową przynależność. Sąd nad Tajemnikiem, nagim względem popełnionej wobec życia zbrodni, jest eschatologicznym rozrachunkiem z doczesnością ${ }^{63}$. Ostatnia spowiedź bohatera obnaża złożony mechanizm konsekwentnego zaprzeczania i wypierania się. Jest chwilą odpominania win, uświadamiania i ostatecznego aktu żalu. Tajemnik, poszukując zakazanego roztajnienia i konsekwentnie przemierzając kolejne rzeczywistości, zdradza nie tylko Boga, ale także samego siebie. Gdy bohater nagi, bezbronny i pokorny pragnie powrócić do początku, okazuje się, że droga jest zamknięta. Ręka „kamienieje w bezruchu”, ponieważ „sama droga postroniła się, widać, unikając grzesznej dłoni” ${ }^{64}$. Nie ma powrotu do poprzedniego stanu, jednak pozostaje nadzieja. Trudno oprzeć się skojarzeniu z postacią Twardowskiego, w której można zobaczyć protoplastę Tajemnika. Do zguby popycha

59 M. Nawrocki, dz. cyt., s. 8.

${ }^{60}$ M. Głowiński, dz. cyt., s. 302.

${ }^{61}$ W. Lewandowski, dz. cyt., s. 54.

${ }^{62}$ Zob. M. Stala, dz. cyt., s. 90-94.

63 „Istota cierpienia (...) zasadza się przede wszystkim na takim sposobie istnienia, który dokonuje się w pustce pomiędzy "ja $\mathrm{i}$ »nie-ja«, tam też rozgrywa się (...) dramat. Dramat nietożsamości, dramat nieidentyczności jest w swojej istocie dramatem - pamięci”. M. Nawrocki, dz. cyt., s. 229.

${ }^{64}$ B. Leśmian, Jan Tajemnik, dz. cyt., s. 96. 
obu żądza posiadania, podsycana ślepą ufnością w siłę rozumu. Obaj kładą na szali własne życie i tracą je. Niewypowiedziany strach przed piekielnymi czeluściami i żal wobec winy ratuje ich zaprzedane dusze, a boska sprawiedliwość skazuje je na wiekuiste wygnanie. Zarówno Twardowski, jak i Tajemnik, odarci z życia, trwają w zawieszeniu między czasem a nieskończonością, bytem a niebytem i wreszcie między Absolutem a samym sobą

Kluczową rolę dla odczytania filozoficznego sensu klechdy Leśmiana odgrywają wspomniane już wcześniej liczne stylizacje i nawiązania biblijne ${ }^{66}$. Bóg i szatan są elementami ludowych wierzeń. Zderzenie dwóch antynomicznych sił, pomiędzy którymi błąka się ociemniały człowiek, potęguje tragizm losów bohatera ${ }^{67}$. Przysięga złożona diabłu przez Tajemnika nie tylko zaprzepaszcza wrodzoną chłopskość Jana, ale także odsuwa od właściwego mu poczucia religijności. Pan Piórkowski - kusiciel, jako twór przebiegły pragnie ostatecznie i wiekuiście zawładnąć człowiekiem. Szatan zwodzi i przede wszystkim wyrzeka się ojcowania, by bez skrupułów obezwładnić bezradny byt ludzki. Stwierdza: „Mój jesteś, bom cię kupił!” ${ }^{68}$. Podstępnie zdobywając ludzką duszę, przypisuje sobie prawo własności wobec duszy Tajemnika i zawzięcie dąży do zguby bohatera.

Co zdumiewające, Bóg jest tylko wspominany przez bohaterów klechdy, nie ujawnia jednak swojej obecności. Absolut wymownie milczy, a mimo to właśnie o Nim wielokrotnie toczy się dysputa. Bóg jest ontologicznym Ojcem wszechrzeczy, którego człowiek wyrzeka się wraz z grzechem pierworodnym. Jest niezawodną ostoją i jednocześnie uosobieniem niedosięgnionej inicjacji. Tajemnik w tej perspektywie ucieleśnia uniwersalizm losów człowieka, od prapoczątku stającego w obliczu pokusy penetracji zakazanego. Historia jednostki zatacza koło i tajemnica wyobcowania indywiduum zostaje obnażona, a rajska żądza poznania po raz kolejny skazuje na wygnanie. Bohater ma wokół siebie otchłań, w której błąka się po omacku. „Tajemnik wywija się bytowi, tak jak się niebytowi wywiną "69. Takie uwięzienie w międzyświecie, między niebem a piekłem, akcentuje swoiste niedokonanie, niedookreślenie i wreszcie też ową „bosość” wyrażającą dojmującą niemożność poznawczą ${ }^{70}$.

${ }^{65}$ Nawrocki pisze, iż: „dramat człowieka jest dramatem doświadczania istnienia i nieistnienia”. Tenże, dz. cyt., s. 217.

${ }^{66}$ Nawiązania między innymi do Księgi Genesis, Apokalipsy, Księgi Psalmów i do Księgi Hioba.

${ }^{67}$ Por. A. Czabanowska-Wróbel, dz. cyt., s. 226.

68 B. Leśmian, Jan Tajemnik, dz. cyt., s. 96.

${ }^{69}$ P. Matywiecki, dz. cyt., s. 112.

70 Jak twierdzi Nawrocki: „Istnienia zgłębić się nie da, zawsze zostaje coś nienazwanego, coś nieokreślonego, w najlepszym wypadku coś niedookreślonego, dotyczy to wszystkich form istnieniowych, w tym - przede wszystkim - człowieka. (...) Leśmianowską tajemnicę pojmować należy jako kategorię ontyczną, tajemnica jest jednocześnie zasadą bytu i jego manifestacją. Byt w swojej istocie jest noumenalnie tajemniczy i jednocześnie aktualizuje się jako tajemniczy fenomen”. Tenże, s. 218. 
Człowiek odrzucający wrodzony instynkt i wiedziony rozumem, a więc zmierzający do uświadomienia, z góry skazany jest na porażkę. Pobrzmiewa w tej tezie bergsonowskie rozgraniczenie intuicji (instynktu) i intelektu. „Intelekt staje się zabójczy dla życia"71, gdyż prowadzi do świadomości, a ta burzy idealną harmonię z życiem. Intuicja natomiast będąc siłą pierwotną wpisaną w naturę ludzką, opiera się na działaniu bez uświadamiania i dzięki temu stanowi jedyną bezbolesną drogę prowadzącą do poznania. W postępowaniu Tajemnika intuicja zostaje zanegowana na rzecz dyktatury umysłu. Tragizm wyboru polega na wystąpieniu przeciw porządkowi rzeczy i dążeniu do podporządkowania potęgi witalizmu bezwarunkowej ludzkiej dominacji. Jak słusznie zauważa Rowiński: „Cywilizacja mieszczańska (...) egzystuje na poziomie świata zjawisk, a nie rzeczy samych w sobie, zjawisk, które są wytworami intelektu, i nie stwarza ona możliwości przebicia się w głębsze pokłady istnienia"72. Jednak to życie jest kreatorem i celem, a człowiek, jako podległa mu i przez nie wypełniona forma, paradoksalnie pozostanie ( $\mathrm{w}$ równości z innymi byta$\mathrm{mi}$ ) wiecznie niespełnionym poszukiwaczem szczęścia. Odtajemniczanie postaci obrazuje sukcesywny proces destrukcji esencjonalności ludzkiej natury, z której cywilizacja wysysa istotowość, po to tylko, by jednostkę później brutalnie obnażyć i piekielnie pochłonąć.

Przestrzeń zaświatowa przez odwrócenie porządków zaburza rytm zdroworozsądkowego pojmowania, a odzierając bohatera z wszelkich zbytków nieprzypisanych jego przyrodzeniu, uświadamia go w własnej skalanej grzechem naturze człowieczej ${ }^{73}$. Tajemnik chłop, zawłaszczając czerwone buty, wyzbywa się swego i wraz z tym wkracza w sferę nie-swoją, odwrotną, nabytą. Końcowy gest, traktowany jako próba zamknięcia rozpoczętego znaku krzyża, jest metaforycznym powrotem do tego, co chłopskie, a więc pierwotnie właściwe, indywidualne i przejawiające się w jakże ufnym zawierzeniu się milczącemu Bogu.

„Człowiek w poezji Leśmiana - jak interpretuje Rowiński - nie jest ściśle określony ani przez historię, ani przez geografię" 74 . Bohater zostaje wyjęty z linearnego czasu i wrzucony w przestrzeń własnego wnętrza po to, by zmierzyć się z samym sobą. Realia społeczne są pretekstem do ukazania złożonego procesu odtajemniania, dochodzenia do prawdy. Bohater, jak tragiczna pacynka, zostaje wpędzony w ślepe konwenanse, które kształtują w nim jego własny, fałszywy obraz. Następnie, dla iluzji zrzekając się swojej podmiotowości, uzależnia się od destrukcyjnej woli losu, tylko po to, by dostrzec, że do życia potrzebuje zakorzenienia w aksjologii, której uprzednio się wyrzekł.

${ }^{71}$ C. Rowiński, dz. cyt., s. 96.

72 Tamże, s. 194.

73 Choć nie o grzech tu chodzi, lecz o wyrzeczenia się samego siebie w imię nieuzasadnionej żądzy.

${ }^{74}$ C. Rowiński, dz. cyt., s. 201. 
Świat baśni - pisze Matywiecki - rozpoczyna się od niejawnej i jawnej nazwiskowej dziwności bohatera. Pod jej paradoksalnym znakiem rozwija się także mowa tego świata, tajemnicza i zarazem trafna. Mowa ta jest wytworem społecznego świata społeczność (dla niej przecież opowiada się baśń) chce przy pomocy swojej mowy poznać niepoznanego, „roztajnić” Tajemnika ${ }^{75}$.

Odarcie z maski społecznej odsłania sedno tajemnicy o indywiduum, które usilnie poszukuje stanowiącej o nim prawdy. Ułomna ludzka percepcja nie pozwala na zaspokojenie ciekawości transcendentnej niewiadomej, a próba ujawnienia pierwotnej istoty jestestwa naznacza Tajemnika świadomością niezaspokojonego braku. Odkrywa on jedynie, iż ciążą na nim, właściwe kondycji ludzkiej, ciągła niedookreśloność i niemoc poznawcza.

Tajemnik zawsze tkwi w dysharmonii. Bohater pozostaje uwięziony między skrajnościami, a jego przeznaczeniem jest wisieć aż do śmierci w sposób przeciwny stanowi naturalnemu. Wszelkie porządki są nieustanie zakłócane, właściwe prawa odwracają się i mieszają. „To bowiem, co umieszczone na dole, może się znaleźć na górze; to zaś, co plasuje się w górze, można przesunąć w dół"76. Człowiek schodzi do podziemi - upiór wychodzi na świat. „Odwrócony” Tajemnik traci dukaty, czapkę, odzienie, materię i zostaje sam na sam ze swoją duszą wobec przestrzeni bezmiaru.

Jednostka, zniewolona przez społeczne konwenanse, usankcjonowana przez system ról, kanonów, niepodważalnych systemów aksjologicznych, wszczyna bunt i stara się wyjść poza nadaną jej istotowość. Poprzez użycie motywów nadrealistycznych, fantastycznych ukazane zostaje ograniczenie postaci, jej małość, słabość, ułomność. Pozorne wyzwolenie z tych okowów daje złudną wolność, która prowadzi do bolesnego upadku. Bohater przechodzi proces demaskacji - od iluzji posiadania i panowania do przekonania o „całkowitym braku”, nie tylko w sferze percepcji, ale także w zakresie podmiotowości i możliwości wyłącznego decydowania o swoim losie.

Nad wszystkim władzę sprawuje nieokiełznany kreacjonizm poetycki. Tworzenie człowieka i warunkowanie jego psychofizycznej istności stanowi podstawę do mówienia o uniwersalnej kondycji natury ludzkiej, w której kreator nieustanne poszukuje siebie i podobnie jak jego twory pragnie uświadomienia w dramatycznej egzystencji. Wyzwolenie przynosi charakterystyczny dla Leśmiana śmiech - czarny, rubaszny humor, a więc taki, którego użycie służy „do przezwyciężenia strachu i tragizmu egzystencji"77.

\footnotetext{
75 P. Matywiecki, dz. cyt., s. 107.

M. Głowiński, dz. cyt., s. 294.

77 C. Rowiński, dz. cyt., s. 64.
} 


\section{Bibliografia}

Bettelheim B., Cudowne i pożyteczne. Znaczenie i doniostość baśni, tłum. D. Danek, „Teksty. Teoria literatury, krytyka, interpretacja” 1980, nr 1.

Czabanowska-Wróbel A., Baśń w literaturze Mtodej Polski, Kraków 1996.

Głowiński M., Zaświat przedstawiony. Szkice o poezji Bolestawa Leśmiana, Kraków 1998.

Gorczyńska M., Miejsca Leśmiana. Studium topiki krytycznoliterackiej, Kraków 2011.

Leśmian B., Jan Tajemnik [w:] tegoż, Klechdy polskie, wstęp, oprac. W. Lewandowski, Kraków 1999.

Leśmian B., Szewczyk [w:] tegoż, Poezje wybrane, oprac. J. Trznadel, Wrocław 1983.

Lewandowski W., Wstęp [w:] B. Leśmian, Klechdy polskie, wstęp, oprac. W. Lewandowski, Kraków 1999.

Ligęza L., „Klechdy polskie” Bolestawa Leśmiana na tle folklorystycznym, „Pamiętnik Literacki” 1968, nr 1.

Markowski M.P., Polska literatura nowoczesna. Leśmian, Schulz, Witkacy, Kraków 2007.

Matywiecki P., Czyściec (o baśni Bolestawa Leśmiana "Jan Tajemnik”), http:// www.kwartalnik.art.pl/wp-content/uploads/2015/06/kwartalnik17.pdf, dostęp: 20.11.2018.

Moszyński K., Kultura ludowa Stowian, t. 2, Warszawa 1967.

Nawrocki M., Wariacje istnieniowe. O ontologii poetyckiej Bolestawa Leśmiana, Tarnów 2009.

Nola A.M. di, Diabet, tłum. I. Kania, Kraków 2000.

Pachocki D., Filologia i historia. "Klechdy polskie” Bolestawa Leśmiana i inne urwane tropy, „Teksty Drugie” 2014, nr 2.

Pankowski M., Leśmian czyli bunt poety przeciw granicom, tłum. A. Krzewicki, Lublin 1999.

Rowiński C., Cztowiek i świat w poezji Leśmiana. Studium filozoficznych koncepcji poety, Warszawa 1982.

Rożek M., Diabet w kulturze polskiej. Szkice z dziejów motywu i postaci, Kraków 1993.

Rymkiewicz M.J., Leśmian. Encyklopedia, Warszawa 2001.

Stala M., Jam jest miejsce spotkania. Duch, dusza i ciato w poetyckiej antropologii Bolestawa Leśmiana [w:] tegoż, Trzy nieskończoności. O poezji Adama Mickiewicza, Bolestawa Leśmiana i Czestawa Mitosza, Kraków 2001.

Szczukowski D., „Bajka, która baje”. O kilku motywach w „Klechdach polskich” Bolestawa Leśmiana, „Jednak Książki” 2017, nr 7.

Trznadel J., Twórczość Leśmiana (Próba przekroju), Warszawa 1964.

Zięba J., Bolestawa Leśmiana światopogląd nowoczesny. O eseistyce poety, Kraków 2000.

Zimand R., Preliminaria do klechd Leśmiana [w:] Studia o Leśmianie, red. M. Głowiński, J. Sławiński, Warszawa 1971. 